\title{
Daya Antibakteri Ekstrak Etanol Ketepeng Cina (Senna alata) terhadap Staphylococcus aureus dan Escherichia coli secara In Vitro
}

\author{
Taswin Yacob ${ }^{1)}$, dan Rita Endriani ${ }^{2^{*}}$ \\ 1)Bagian Saraf, Fakultas Kedokteran, Universitas Riau, \\ 2)Bagian Mikrobiologi, Fakultas Kedokteran, Universitas Riau, \\ Jl. Diponegoro No. 1 Pekanbaru \\ Diterima 18-08-2009 Disetujui 06-03-2010
}

\begin{abstract}
The benefit and efficacy of ketepeng cina (Senna alata) in the treatment of infection has shown that have antibacterial activity, inhibiting and killing bacteria that cause infection. The objective of this study was evaluate the antibacterial activity of ketepeng cina against Staphylococcus aureus dan Escherichia coli in vitro. This study was a laboratory experimental research which use completely randomized design with diffusion method. Ethanol extract of Senna alata leaves devided into 4 doses, i.c. 100, 50, 25 and 12.5. Amoxiclave were used as positive control and aquadest negative control. The data were analyzed by Analysis of Varian continued with Duncan's Multiple Range Test. The result of this study showed that antimicrobial activity of ethanol extract Senna alata leaves inhibited the growth of Staphylococcus aureus, but not Escherichia coli. The optimum effect was showed given by the concentration 100 at $17.7 \mathrm{~mm}$.
\end{abstract}

Keywords: antibacterial activity, Escherichia coli, in vitro, Senna alata extract, Staphylococcus aureus

\section{PENDAHULUAN}

Salah satu tanaman obat yang sering digunakan masyarakat untuk pengobatan tradisional adalah ketepeng cina (Senna alata) termasuk ke dalam famili Leguminosae. Bagian dari tanaman ini yang sering digunakan masyarakat sebagai obat adalah daunnya untuk mengobati infeksi bakteri seperti ulkus kulit, sifilis, bronkitis, infeksi jamur seperti panu, kurap, eksim dan infeksi parasit seperti malaria.

Senna alata telah digunakan secara tradisional di berbagai negara di dunia. Di Brazil, Ghana, Meksiko, Peru dan Samoa Senna alata digunakan untuk pengobatan ringworm. Di Ghana Senna alata digunakan untuk berbagai bentuk infeksi jamur. Di Indonesia, salah satu produk tissue pembersih dengan bahan baku utama Senna alata mengklaim dapat mencegah dan mengobati keputihan (Tan, 2001; Tilaar, 2008).

Staphylococcus aureus (S. aureus) dan Escherichia coli (E. coli) merupakan bakteri penyebab terbanyak infeksi di komunitas dan infeksi nosokomial. E. coli dapat menyebabkan infeksi superfisial berupa pustula, karbunkel, abses, impetigo dan konjungtivitis.

\footnotetext{
*Telp: +62761839264

Email: rita_endriani_fkunri@yahoo.com
}

Selain itu juga dapat menyebabkan muntah, diare pada keracunan makanan. E.colidapat menyebabkan diare, infeksi saluran kemih (ISK), meningitis, peritonitis, mastitis dan septikemia serta pneumoniae. (Sleight \& Timbury, 1995; Brooks et al., 2008).

Aktifitas ekstrak Senna alata sebagai antibakteri telah dibuktikan oleh beberapa hasil penelitian. Penelitian Idu et al., (2006) melaporkan bahwa Senna alata dalam bentuk ekstrak metanol mempunyai daya antibakteri terhadap S. aureus dan E.coli, tetapi ekstrak air hanya aktif terhadap $S$. aureus tetapi tidak aktif terhadap E. coli. Owoyale et al., (2005) melaporkan ekstrak etanol Senna alata dapat menghambat pertumbuhan S. aureus dan E.coli. Nur et al., (2002) melaporkan bahwa ekstrak etanol dan ekstrak air Senna alata dapat menghambat pertumbuhan $S$. aureus tetapi kedua ekstrak tersebut tidak dapat menghambat pertumbuhan E. coli. Selain itu juga melaporkan ekstrak air mempunyai aktivitas antibakteri yang lebih baik dibanding ekstrak etanol.

Berdasarkan hal tersebut maka tujuan penelitian ini adalah untuk mengetahui daya antibakteri ekstrak Senna alata terhadap $S$. aureus dan E. coli secara in vitro. 


\section{BAHAN DAN METODE}

Bahan dan Alat Penelitian. Bahan yang digunakan adalah ekstrak etanol Senna alata, S. aureus, E. coli lempeng agar darah (LAD), agar Endo, agar Saboraoud, agar Mueller Hinton, Nacl 0,9\%, larutan Mc Farland 0,5, cakram amoksiclav dan cakram kosong yang siap pakai. Alat-alat yang digunakan adalah: tabung reaksi, cawan petri, mikroskop, pipet steril, oese, labu erlemeyer, mikropipet, oven, autoklaf, inkubator, mistar dorong (caliper), laminar flow dan sartorius filter cellulosa.

Pembuatan Ekstrak Senna alata L. Sebanyak $700 \mathrm{gr}$ bahan daun Senna alata yang telah dipetik dibuat menjadi simplisia dengan sortasi basah, penegringan, sortasi kering dan perajangan. Daun Senna alata dikeringkan pada suhu kamar, kemudian daun yang telah kering digiling hingga halus. Kemudian ditambhakan $5 \mathrm{~L}$ etanol ke dalam $500 \mathrm{gr}$ bubuk Senna alata tersebut. Proses maserasi ini dilakukan sebanyak tiga kali selama tiga hari untuk masing-masing proses maserasi. Campuran kemudian disaring dan didapatkan maserat sebanyak 4,7 L. Selanjutnya etanol dan air yang terkandung dalam maserat diuapkan dengan menggunakan evaporator sehingga didapatkan $75 \mathrm{gr}$ ekstrak kental. Dengan demikian didapatkan presentase ekstrak-simplisia sebanyak $15 \%$.

Sterilisasi Ekstrak. Ekstrak etanol Senna alata disterilkan melalui penyaringan dengan menggunakan sartorius filter cellulosa.

Uji Sterilitas Ekstrak. Ekstrak etanol Senna alata diinokulasikan pada lempeng agar darah dan agar sabouraud, kemudian diinkubasikan pada suhu $37^{\circ} \mathrm{C}$ selama 24 jam. Ekstrak dinyatakan steril jika tidak terdapat pertumbuhan bakteri pada agar darah dan jamur pada agar sabouraud.

Bakteri Uji. Staphylococcus aureus (S. aureus) dan Escherichia coli (E. coli) yang merupakan biakan murni dilakukan peremajaan kembali (subkultur) pada agar darah dan agar endo, diinkubasi selama 24-48 jam pada suhu $37^{\circ} \mathrm{C}$. Isolat $S$. aureus dan $E$. coli telah diuji kepekaannya terhadap amoksiclav yaitu, $S$. aureus sensitif amoksiclav dengan diameternya e" $19 \mathrm{~mm}$ dan E. coli sensitif amoksiclav dengan diameternya e" 18 mm (Wikler MA et al., 2007). Dari koloni-koloni yang tumbuh kemudian dibuat suspensi bakteri uji dengan larutan $\mathrm{NaCl}$ fisiologis sampai kekeruhan sesuai dengan standar Mc Farland 0,5 yang diperkirakan mengandung lebih kurang $10^{8} \mathrm{cfu} / \mathrm{ml}$. Selanjutnya digunakan sebagai bakteri uji.

Pengenceran Ekstrak. Untuk mendapatkan konsentrasi $100 \%, 10$ gr ekstrak ditambahkan ke dalam $10 \mathrm{ml}$ aquades. Selanjutnya ekstrak dengan konsentrasi $100 \%$ diencerkan dengan aquades sesuai rumus $\mathrm{M}_{1} \times \mathrm{V}_{1}=\mathrm{M}_{2} \times \mathrm{V}_{2}$

Cakram. Cakram yang digunakan adalah cakram siap pakai dengan diameter $6 \mathrm{~mm}$ yang diproduksi oleh Micherey-Nagel, Jerman. Setelah cakram disterilkan dengan autoclav selanjutnya dicelupkan ke dalam masing-masing larutan ekstrak sesuai dengan konsentrasi ekstrak yang diperlukan lebih kurang 1 menit.

Penentuan Daerah Bebas Bakteri dengan Metode Cakram (Difusi). Suspensi bakteri dioleskan merata pada permukaan agar Mueller Hinton $(\mathrm{MH})$ dengan kapas lidi steril. Kemudian masing-masing cakram sudah dicelupkan ke dalam ekstrak etanol Senna alata dengan konsentrasi $100 \%, 50 \%, 25 \%$, $12,5 \%$, cakram amoksiclav sebagai kontrol positif, dan aquades sebagai kontrol negatif selanjutnya diletakkan secara aseptis menggunakan pinset steril pada permukaan agar $\mathrm{MH}$. Semua kegiatan ini dilakukan dalam laminar flow. Selanjutnya agar $\mathrm{MH}$ dengan cakram-cakram dan kontrol dimasukan ke dalam inkubator dengan suhu $37^{\circ} \mathrm{C}$ selama 24 jam.

Setelah 24 jam dapat dilihat daya antibakteri berupa zona bening (clear zone) atau hallo di sekitar cakram, sedangkan yang tidak mempunyai daya antibakteri tidak akan menghasilkan clear zone. Selanjutnya diameter yang terbentuk diukur dengan caliper

Analisis data. Hasil yang diperoleh diolah dengan menggunakan ANAVA untuk mengetahui perbedaan bermakna daya hambat berbagai konsentrasi. Kemudian uji dilanjutkan dengan Duncan Multiple Range Test (DNMRT) untuk mengetahui perbedaan yang signifikan antarperlakuan dengan taraf kesalahan $5 \%$.

\section{HASIL DAN PEMBAHASAN}

Hasil uji daya antibakteri ekstrak Senna alata dengan metode cakram (difusi) terhadap S.aureus dan E. coli secara in vitro dapat dilihat pada Gambar 1 dan Gambar 2. Pada S. aureus terbentuknya clear zone/ zona bening di sekitar cakram karena ekstrak Senna alata mempunyai daya antibakteri terhdap $S$. aureus. 
Diameter clear zone/zona bening yang terbesar terdapat pada amoxiclav sebagai kontrol positif yaitu $21,3 \mathrm{~mm}$, diikuti oleh ekstrak $100 \%$ sebesar $17,7 \mathrm{~mm}$, ekstrak $50 \%$ sebesar $15 \mathrm{~mm}$, ekstrak $25 \%$ sebesar $9,7 \%$ dan ekstrak 12,5\% sebesar $7 \mathrm{~mm}$. Aquades sebagai kontrol negatif tidak membentuk daerah bebas bakteri karena diameternya tetap $6 \mathrm{~mm}$. Untuk lebih jelasnya dapat dilihat pada Gambar 1.

Pada E. coli ekstrak Senna alata tidak mempunyai daya antibakteri terhdap E. colikarena tidak terbentuk clear zone/ zona bening disekitar cakram. Clear zone/ zona bening hanya terbentuk pada amoksiclav dengan diameter sebesar $27 \mathrm{~mm}$ dan aquades sebesar $6 \mathrm{~mm}$. Untuk lebih jelasnya dapat dilihat pada Gambar 2.

Terbentuknya clear zone / zona bening pada penelitian ini berarti ekstrak Senna alata mempunyai daya antibakteri terhadap $S$. aureus tetapi tidak terhadap E. coli. Perbedaan diameter clear zone/zona bening pada $S$. aureus dalam berbagai konsentrasi disebabkan perbedaan konsentrasi zat aktif yang ada dalam ekstrak Senna alata tersebut. Hasil penelitian menunjukkan semakin tinggi konsentrasi maka semakin luas zona bening yang terbentuk. Konsentrasi $100 \%$ mempunyai diameter clear zone/zona bening yang
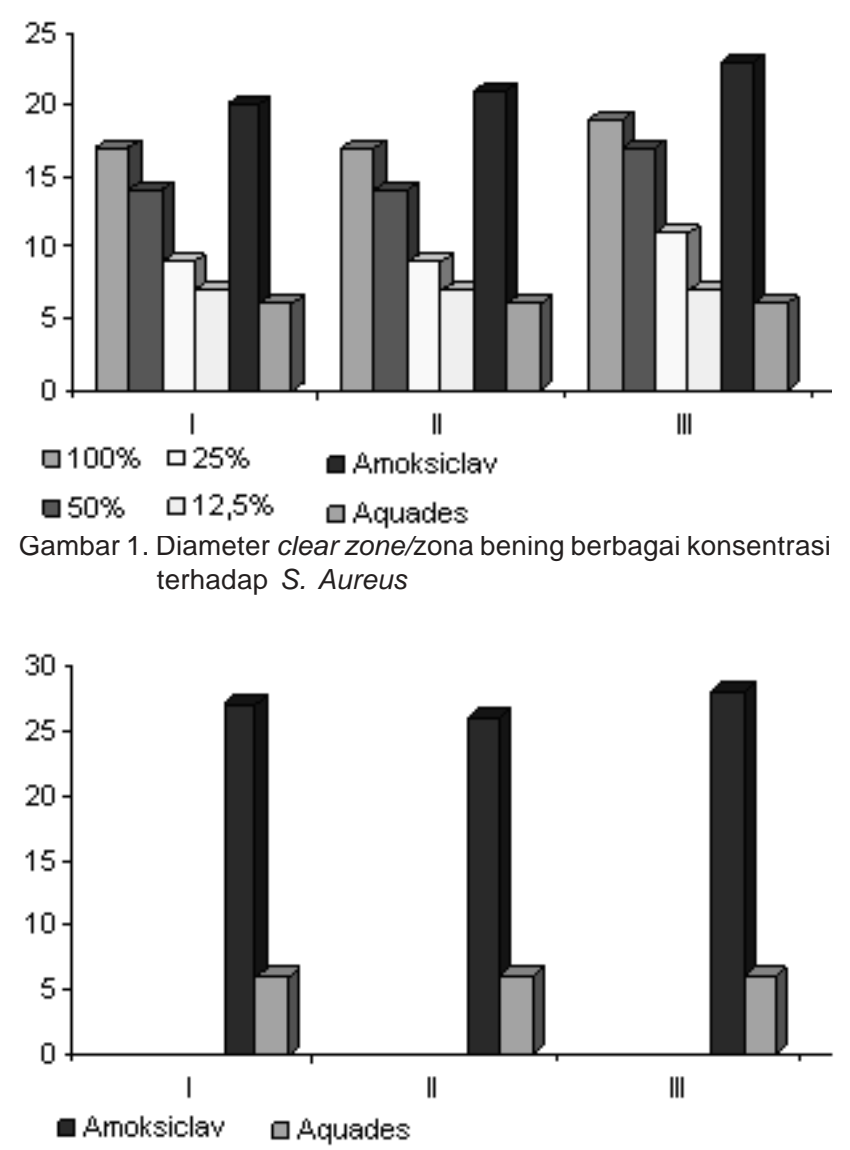

Gambar 2. Diameter clear zone/zona bening berbagai konsentras terhadap E.coli paling besar dibandingkan dengan konsentrasi lainnya. Hal ini menunjukkan bahwa konsentrasi mempengaruhi daya kerja obat terhadap bakteri, sehingga. semakin tinggi konsentrasi ekstrak Senna alata, semakin banyak pula zat aktif yang terkandung di dalamnya sehingga kemampuan menghambat pertumbuhan $S$. aureus juga lebih besar.

Hasil penelitian diolah secara statitistik dengan menggunakan anava, didapatkan hasil yang berbeda nyata antara perlakuan terhadap $S$. aureus pada $\mathrm{p}<$ 0,05. Hasil Duncan New Multiple Range Test (DNMRT) bahwa konsentrasi $100 \%$ berbeda nyata jika dibandingkan dengan konsentrasi $50 \%, 25 \%, 12,5 \%$, amoxiclav, dan aquades. Artinya efek antibakteri $100 \%$ lebih baik dibandingkan dengan konsentrasi $50 \%, 25 \%$, $12,5 \%$ dan aquades, tetapi lebih rendah dibandingkan amoxiclav. Konsentrasi $50 \%$ berbeda nyata dibandingkan dengan konsentrasi $25 \%, 12,5 \%$, amoxiclav dan quades.Artinya konsentrasi $50 \%$ mempunyai efek antibakteri yang lebih baik dibandingkan konsentrasi 25\%, 12,5\% dan aquades, tetapi lebih dibandingkan amoxiclav. Konsentrasi $25 \%$ berbeda nyata dibandingkan dengan $12,5 \%$, amoxiclav dan aquades. Artinya efek antibakteri konsentrasi $25 \%$ lebih baik dibandingkan 12,5\% dan aquades, tetapi lebih rendah dibandingkan amoxiclav.

Hasil penelitian ini sesuai dengan hasil penelitian Nur et al., (2002) bahwa ekstrak etanol dan ekstrak air Senna alata dapat menghambat pertumbuhan $S$. aureus tetapi kedua ekstrak tersebut tidak dapat menghambat pertumbuhan E. coli.

Hasil penelitian ini juga berbeda dengan penelitian Idu, et al., (2006) yaitu ekstrak metanol Senna alata bisa menghambat pertumbuhan $S$. aureus dengan diameter clear zone/zona bening sebesar $5 \mathrm{~mm}$ dan terhadap E. coli $10 \mathrm{~mm}$. Hal ini dapat disebabkan karena menggunakan jenis ekstrak yang berbeda sehingga zat aktif yang tertarik juga berbeda akibatnya kemampuan menghambat pertumbuhan bakteri juga berbeda.

Selain itu diameter clear zone/zona bening yang terbentuk dari hasil penelitian ini pada konsentrasi $12,5 \%$ berbeda dan lebih kecil dibanding dengan hasil Oyowale et al., (2005) yaitu untuk S. aureus sebesar $5 \mathrm{~mm}$ dan E. coli sebesar $10 \mathrm{~mm}$. Hal ini dapat disebabkan oleh faktor biologi dan faktor kimia dari tanaman Senna alata tersebut. Faktor biologi dapat berupa lokasi tanaman asal yaitu dipengaruhi oleh 
tanah, atmosfir, energi, senyawa organik dan anorganik, umur, pemanenan dan penyimpanan. Faktor kimia dapat berupa komposisi kualitatif dan kuantitatif zat aktif yang terkandung dalam ekstrak. Selain itu juga bisa dipengaruhi oleh metode ekstraksi dan ukuran bahan (Komarawinata, 2008).

Terbentuknya clear zone/ zona bening disekitar cakram ini disebabkan karena kandungan kimia dari ketepeng cina ini yaitu antara lain:minyak atsiri, glikosida, alkaloid, flavonoid, antraquinon, saponin dan tanin (Idu et al., 2006; Mahmood et al., 2008). Senyawa - senyawa tersebut merupakan senyawa fenolik yang artinya memiliki gugus fenol. Cara kerja gugus fenol sebagai antibakteri adalah dengan cara berinteraksi dengan sel bakteri melalui proses adsorbsi yang melibatkan ikatan hidrogen. Gugus fenol pada konsentrasi 1,0\% bersifat bakterisid karena dapat menyebabkan koagulasi protein dan membran sel bakteri mengalami lisis. Konsentrasi 0,2\% bersifat bakteriostatik karena terbentuk kompleks protein fenol dengan ikatan yang lemah dan diikuti penetrasi fenol ke dalam sel bakteri yang dapat menyebabkan presifitasi dan denaturasi protein intraseluler pada sel bakteri (Bruneton, 1993). Selain itu tanin dapat melisis sel bakteri serta minyak atsiri yang dapat bersifat sebagai koagulator protein. Protein yang menggumpal tidak dapat berfungsi lagi sehingga akan mengganggu pembentukan dinding sel bakteri. Lisisnya sel bakteri tersebut disebabkan karena tidak berfungsinya lagi dinding sel yang mempertahankan bentuk dan melindungi bakteri (Brooks et al., 2008).

\section{KESIMPULAN}

Ekstrak etanol Senna alata mempunyai daya antibakteri terhadap $S$. aureus tetapi tidak mempunyai daya antibakteri terhadap E. coli. Daya antibakteri terhadap S. aureus dibuktikan dengan terbentuknya clear zone disekitar cakram yang mengandung ekstrak dengan diameter terbesar adalah $17,7 \mathrm{~mm}$.

\section{UCAPAN TERIMA KASIH}

Penulis mengucapkan terima kasih yang sebesarbesarnya kepada Laboratorium Kimia Organik FMIPA dan Laboratorium Mikrobiologi Fakultas Kedokteran Universitas Riau atas segala fasilitas dan kemudahan yang diberikan kepada penulis selama melaksanakan penelitian ini.

\section{DAFTAR PUSTAKA}

Brooks, G.F., Butel, J.S. \& Morse, S.A. 2008. Jawetz, Melnick, \& Adelberg's Mikrobiologi Kedokteran, Edisi 1 Buku 2. Jakarta: Salemba Medika.

Bruneton, J. 1993. Pharmacognosy, Phytochemistry, Medical Plant, New York Lavoiser Publising Inc. 180-1.

Idu, M., Oronsaye, F.E., Igeleke. \& Omonigho, S.E. 2006. Preliminary investigation on the phytochemistry and antimicrobial avtivity of Senna alata L, Journal of Applied Science 6(110): 2481-5.

Komarawinata, A. 2008. Budidaya dan Pasca Panen tanaman Obat untuk meningkatakn Kadar bahan aktif. Unit Riset dan pengembangan PT. Kimia Farma (Persero). Tbk.

Mahmood, E.A.M. \& Doughari, J.H. 2008. Phytochemical screening and antibacterial evaluation of the leaf and Root extract of Cassia alat Linn, African Journal of Pharmacy and Pharmacology 2(7): 124-129.

Nur, E.I., Somchit, M.N., \& Abdul Rahim, M. 2002. In Vitro Antibacterial Activity And Effect Of Cassia Alata In Livers Of Mice; Proceedings of the Regional Symposium on Environment and Natural Resources, Kuala Lumpur Malaysia 1: 509-515.

Oyowale, J.A., Olatunji, G.A. \& Oguntoye, S.0. 2005. Antifungal and antibacterial activities of an Alcoholic extract of Senna alata Leaves; Journal of applied Sciences and Enviromental Management 9(3): 105-107.

Sleigh, J.D. \& Timbury, M.C. 1994. Notes on Medical Bcateriology. $4^{\text {th }}$ edition. London. Churchill Livingstone.

Tan, R. 2001. Tropical Plant Database ; www.rain-tree.com (09 Desember 2008).

Tilaar, M. 2008. Herbs product. http://www.sariayu.com (27 Januari 2009).

Wikler, M.A. et al. 2007. Peformance Standards for Antimicrobial Susceptibility Testing; Seventeent Informatical Suplement. Clinical and Laboratory Standard Institute;27(1). 